\title{
Thinking of the academic burden on students and education reform mode of occupation education
}

\author{
ZHANG Liping \\ Weifang Vocational College, Wei Fang, 261041, China.
}

Keywords: vocational education; Schoolwork burden; The introduction education reform

\begin{abstract}
The student schoolwork burden overweight problem is an obstacle to promote quality education, from central to local levels of schoolwork burden overweight problem has also been highly attention, this article analyses the reasons of the student schoolwork burden overweight, and put forward the measures to reduce the financial burden of students, from promoting the new curriculum reform, rebuild evaluation pattern, strengthen the teacher training, improve quality, strengthen the vocational education and other aspects, mix, can really reduce the heavy schoolwork burden.
\end{abstract}

\section{Introduction}

Workloads, seems to have become the pronoun of today's students pressure; Seems to have become the focus topic of justice for students; Indirect criticisms seems to have become a strong evidence in today's teacher. Under the huge pressure of public opinion, the department of education and therefore put forward to promote the curriculum reform, and therefore, in the national program for medium and long-term education reform and development of the word \"burdenl" appear frequently. Schoolwork burden in today's society has been the default is a pressure on baby head of a mountain.

For schoolwork burden, however, the historical roots, schoolwork burden of original intention, not too many people. Schoolwork burden is a word has been killed by a stick, not a lot of people pay attention to its positive significance. A few people $\backslash " \backslash "$ casel" for it. Because in today's society is so impetuous, only few people can calm down to think about a problem. Many people think that schoolwork burden is too heavy, then don't homework for the children. With such understanding, we remain silent, said speechless. What don't want to argue with them, because time is innocent.

Teachers often find many of the students even, the night sleep, struggling to cope with homework, sports and all kinds of exercise time is squeezed out, the smile on the face is no longer common. Shandong TV had a public-service advertisement \"let each student easy life, joyful growth $\backslash "$, the background is a student's bag is more and more heavy, told us the student schoolwork burden overweight, affect the implementation of the national education policy, the implementation of quality education, seriously affect the students' all-round development, we need to reduce the heavy burden of students.

Both from the dialectical materialism and from the perspective of the zhouyi, as we all know the occurrence of any one thing has both positive and negative meaning, and we treat schoolwork burden in the question, how do you like the red envelopes, do bad thing, say nonsense? I do not deny that the schoolwork burden is heavy, but I definitely can't agree to cancel all the homework.

\section{Analysis of the causes of the heavy academic burden of students}

The analysis of the causes of student schoolwork burden overweight holiday roaming the streets, you will find that the children \"groups।", for a variety of in and out of class. From Monday to Friday, in the morning you will find that the large and small students carrying or pulling all kinds of bag walk path in countryside, you will find flowers of the motherland, take the lights at night on photosynthesis, is thriving. Teenagers, a good future of the motherland. Don't know one day he will 
grow into towering trees, become the backbone of the motherland, will be like a greenhouse flowers, not through wind and rain have withered. Why, the growth of the children need to pay such a price?

\section{Fierce competition of society}

No one can deny that in today's society of fierce competition, more no one denied that the weak can enjoy high quality life. In this dog-eat-dog society, you can't have no skill, you can't afford not to be somebody. For thousands of years long, a less-pressured has been constant pursuit of family education. Social competition must has some of the victims, however, unavoidably affected, good, the children are innocent act as the role. Competition of ideas already materialized a variety of classes for the children, typically exposes. Parents busy with work, the children were also busy work. Think of it, for a child, it is a simple child study habits, to develop the children's time? Children have time schedule? This is not a burden? Children still have time to experience life? The competitive society have heads toward the child. Education evaluation of the single

\section{In such a pluralistic society, needs more diversified.}

Diversifying requires diversified education goal. All this seems to be no wrong, but the most fundamental evaluation of a single way of limit the diversity of education goals. No teacher never think according to their aptitude, differential treatment in education. But test scores, like a naked maiden shameless in education. Evaluation on each silently teacher pay, bad grades, it denied all education achievements. In education, performance evaluation become a king. Just because of such evaluation, teachers began to the kind of \"I will search up and down।" and thus the enthusiasm was relentlessly erode. One day, the teachers began to hate, to education evaluation question and resistance. They never to fight again, they understand the knowledge, they learned to cherish life, in order to not to kill a bud bud, would rather do logistical work. However, some teachers didn't see the present education of practical work, every day up earlier than chicken, sleep later than a dog, so struggle in teaching a line. In order to bring out the scores, at all costs, their own life is their own, student life is their own, a lot of homework. Poor students become soldiers in the exam this war without gunsmoke.

For students, it is not? Test results can become the student to the only standard to higher education. A day early, late, midnight oil children in order to be able to enter such as high level of institution of higher learning, under unbearable weight. A MOE course, piles, examination, bring pressure to the children is in the invisible. Schoolwork burden before can no longer follow the purpose, follow before the orbit of development. It has been alienation.

\section{Faculty}

Have so a word, can cut wood, a hatchet to; Won't cut wood, ten axe is useless. Under the current evaluation system, part of the teacher to grade, put all your eggs in one basket. Due to their teaching ability in general, a lot of problems can't give students speak in class. Cause students to master some difficult, but in order to achieve the purpose of the master, is not so all unscrupulous homework to the student, on the run from the students master the knowledge in practice. This kind of phenomenon in the rural areas is especially rare.

\section{Unbalanced course content, course structure is not reasonable}

Have teacher described the survival state of the current students: \"they have ambition, but lack of fighting spirit with their feet on the ground, and they are positive, but a lack of will to fight hard and perseverance; they crave more love, but often do not pay attention to care for others, lack of compassion, they pursue the good life, but are often reluctant to pay more for labor; their intellectual development faster, knowledge is more wide, but beginning ability, practice ability is poor; they are adults are established early, but still rely on psychological $\mid$ ". The survival state of the 
students that learning to live with them in the imbalance of course structure has a great deal of correlation. Current students knowledge schoolwork burden is overweight, practical burden too little. Namely students to undertake studies in cognitive course content too much, the burden is overweight, on practical classes too little bear the course content. School curriculum structure is in a state of imbalance, its outstanding performance is: the $\backslash$ "core classes $\backslash$ " (language), light $\backslash$ "deputy class।" (pronunciation); Light heavy subjects, the exam subjects, the training of the students in academic activities memory occupy the vast majority, and thinking ability, imagination training space towardsreducing it. Our education goal is to develop the art of morality, intelligence and physique full scale development, but in many cases, the basic is the spearhead of intellectual education, intellectual education became the foundation education substantive goals, other children compared with just \"accessories\". This cannot get good mining the student's learning potential. And \"the imbalance of academic elements and schoolwork burden destroyed the scientific nature and the harmony of the whole structure of schoolwork, affects the reasonable knowledge structure and cognitive structure of building, and eventually hindered the students comprehensive harmonious developmentl". Students learn in the life of the elements of the course is not balanced, their structure is not reasonable for students physical and mental growth is a heavy course load, to adverse impact on their physical and mental qualities.

Specification of running a school background, no change the exam-oriented education student schoolwork burden heavier. '"Five yan।" province department of education regulations, strict school standards, regulate the behavior of running a school, may not be super class, holiday (weekend) shall not organize the students make up a missed lesson, provides for students of the school day. Seemingly can reduce the time of student learning, but did not change the college entrance examination scores as the only standard to admit the fact that a good policy is often to be eroded by countermeasures. Now implement the independent admission examination and north of the headmaster's recommendation system $\backslash$ "is not the main see result? The principal dare to recommend $\backslash$ "geeks\"?

\section{Appropriate practical significance to reduce the financial burden of students appropriate student schoolwork burden is helpful to cultivate students' good habits}

American scholar Samuel once said: \"sow thought, reap action; planting behavior, reap habit; a habit, reap character; sow character, harvest fate.l" Habits have great influence in the success or failure of the life. The good habits can make people live better and better and more successful; Bad habits tend to make failure into success. A good learning habits of students, should be able to reasonably arranging their spare time; Should be able to find out my own shortcomings and correct them voluntarily; Should arrange some interested in their spare time, can help you in learning activities. But under the heavy schoolwork burden, deprived homework almost all their spare time. How to develop good habits? Appropriate student schoolwork burden is beneficial to cultivate the students' physical and mental health experts pointed out: mental health refers to a person's good, will improve the normal intelligence, emotion and behavior coordination and moderate reaction, relationship coordination, psychological activities in line with the age characteristics of the mental state, have the courage to overcome difficulties and determination and positive attitude towards life. Score first upon the student's mind, secretly latent zi student unhealthy thoughts. Heavy workloads, must be bored students produce negative mentality and psychology. Bored and rebellious attitude, led to the fear of learning, the students of teacher education, perplexed at the future and life, there are many students and the phenomenon of identity is not consistent. Therefore appeared, such as ।"underachiever।" such as \"problem students।" term \"poor student।". Appropriate student schoolwork burden is advantageous to the comprehensive implementation of quality education, promote the all-round development of students have had a teacher said to me: ।"today's students have not thought about, let I don't know what he was reading.।" Students usually used to deal with. An ancient Greek philosopher once said: ।"the mind is not a container to fill up, but a need to be lighted torch.I" Many students in under the pressure of schoolwork burden, became the only knowledge of containers, not thinking, not innovation. In all learning, lifelong learning, learning 
society, education must be innovative, should pay attention to cultivate and care for the students' curiosity, thirst for knowledge, help students autonomous learning, independent thinking, to protect the students' exploration spirit, innovative thinking, for students' talents and potential fully development to create a relaxed environment. And heavy schoolwork burden, just killing the students' creative thinking.

Appropriate measures to reduce the financial burden of students deepen the education reform, change education idea, reconstruction of education examination evaluation pattern and continue to promote the reform of course teaching administrative departments and schools need to have a clear thought, the purpose of education is to cultivate all-round development of morality, intelligence and physique, rather than cultivating \"dies studies, reads the book, read a book $\backslash$ " the bookworm. Examine schools, teachers teaching quality is right, but the quality of teaching is not only a result of high and low, more want to see the students all aspects of the development. Evaluation approach to diversification, to student's comprehensive quality evaluation can not become a mere formality. This is about to change education idea mentioned the important agenda of reform, guided by modern teaching concept, evaluation of a person, a school. Continue to promote the reform of curriculum, school-based curriculum development, train the students' social comprehensive practice ability, at the same time, the existing teaching materials in the difficult, complex and delete outdated content, a clear knowledge of the teaching goal, lets the student can learn with confidence, become \"want me to learn $\backslash$ " to \"I want to learn \". At the same time, the teaching administrative department should be resolutely enforce national curriculum arrangement, strictly carry out the teaching plan and curriculum are the breakthrough to solve the disadvantages of primary and secondary schools teaching, check the class is full of the school, whether there is any irregularities, and increase the penalties. Strengthen the teacher training, improve teachers' quality, pay attention to the effective teaching student schoolwork burden is the direct cause of teachers' quality problem. To ease the burden on students, must be from two aspects: theory to practice to teacher training, emphasis on effective teaching. To learn advanced teaching idea in theory, serious reflection, and to guide their teaching practice. Practice, requires teachers to strictly comply with the requirements of the $\backslash$ "five yan\", earnestly implement the $\backslash$ "five $\backslash "$ earnestly, optimizing teaching methods, to further explore the suitable teaching method, learning to build with students as the center, the new teaching model based on the students' activities, organizing students to carry out exploratory, research-based learning activities, must pay attention to student's thought morals quality, psychological quality, learning attitude and learning habits, cooperation spirit and the cultivation of innovation spirit. Publicity, strengthening the vocational education, alleviate employment pressure of the vocational education is relatively backward in our country, the development of enterprises and even the development of national economy lack of senior skilled worker. College students ।"hammering wooden bridgel". College is to obtain employment, in order to pass the score is required. Students' burden and enters a higher school employment, strengthen job training, and expand employment is a potential way to reduce the financial burden on students. Therefore, must promote the relevant national vocational education policy, improve the social from all walks of life to the understanding of the vocational education, especially to improve the recognition of students and parents, to make the whole society concern, support good atmosphere of vocational education reform and development. Open students' life world

The lack of freedom to make education become a mandatory only discipline, thus fundamentally blocked the enlightenment, also makes the education is no longer for the purpose of cultivating spirit personality. Because of the lack of freedom, people can't go looking for the right purpose of life, people's hearts will never be activated and personal spiritual level of active will be serious. Therefore, the lack of education freedom will have devastating consequences for the healthy development of individuals. Have a comfortable learning space and time, is a prerequisite for the student to obtain independent development. Today, growing class size, living space and communication space of students are becoming more and more narrow; Idealized, high standards of teaching requirements, so that the students busy personal potential for the development of unique and individual character of make public; Frequent heavy study tasks, and excessive examination test, 
make the students' life world and the world becomes heavy and depressed. To student's excessive controls and constraints, are often bound students initiative, inhibiting the students' learning enthusiasm. Students have strong curiosity and thirst for knowledge, to meet the students' innate curiosity and desire for knowledge, to open the life world of students, develop the students' learning space and time, enriching the content of the student's after school life.

\section{Conclusion}

We need an objective and calm analysis of the present in the form of students for the heavy burden, the value of a rational look at moderate schoolwork burden and the harm of the heavy schoolwork burden, put forward feasible measures, and guaranteed the implementation of the real, lift the $\backslash$ "burden\" measures to implement, really for the child to a reasonable air.

\section{Reference}

[1] li-min xie. \"--।" half a century in our country history back and thinking [j]. Journal of jimei university, 2005 (3).

[2] wang yh, Daniel huang. The interests of the elementary education reform subject and its analysis [j]. Journal of contemporary education science, 2006 (4).

[3] Wang Rongqin. Learning difficulties the psychological barriers and its transformation of the underachiever strategies [J], 2001.

[4] Li Kexin, min. The theory of difference of the concept, origin and education measures [J] journal of yantai teachers college (zhe edition), 1998, 2.

[5] Feng Huiling. To expand the functions of - "the crevice time" of archival profession survival strategy [a]. The social memory of the 21 st century, China first archives science dissertation for the Doctoral Forum [C]. Beijing: China Renmin University Press, 2001.105 - 112.

[6] Feng Huiling. Electronic document management tutorial [M]. Beijing: China archives press, 2001 (in Chinese). 